
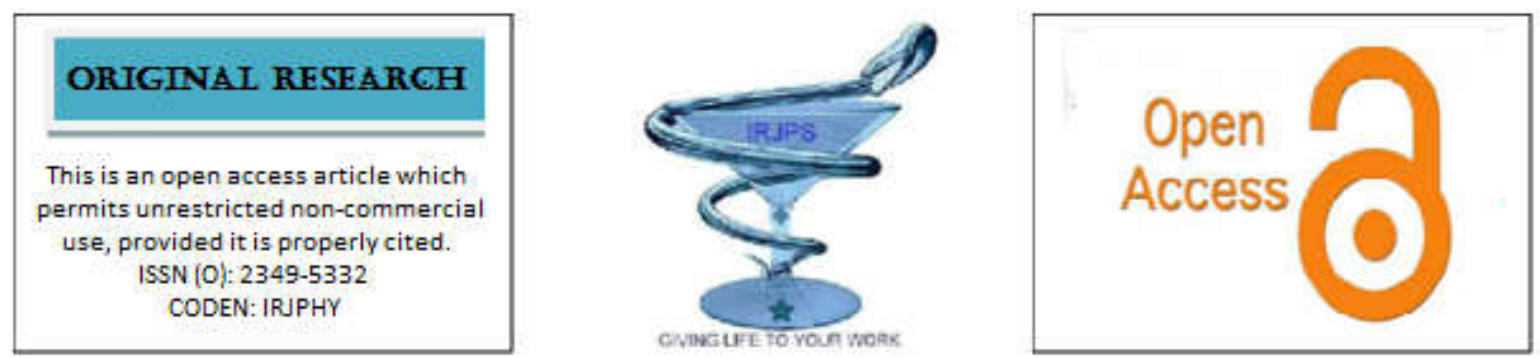

\title{
INVESTIGATION OF THE IMPACTS OF GENDER AND BODY MASS INDEX ON DYSLIPIDEMIA AMONG DIABETIC PATIENTS TREATED IN OUT CLINICS AT ROYAL MEDICAL SERVICES, JORDAN
}

\author{
Khaled Waleed Alkurdi \\ Consultant Emergency Physician, Royal Bahrain Hospital.
}

Submitted on: 18.06.19;

Revised on: 08.07.19;

Accepted on: 18.07.19

\begin{abstract}
:
Introduction: Diabetes is associated aspects metabolic disorder such as dyslipidemia.

Study objectives:The main objective of this study was to investigate the impact of BMI and gender on the occurrence of dyslipidemia in diabetic patients treated outpatient clinics in Royal Medical services, Jordan.

Methods and subjects: This study was a retrospective study. A total of 62 profiles of diabetic patients were included. The following variables were included in the study: age, gender, BMI, and status of dyslipidemia. A working excel sheet was created to make raw data of all participants. The statistical analysis was carried out using SPSS version 21. Data representation included means, standard deviations, and frequencies and percentages. The relationships between variables were computed using Chi-Square tests, One Way Anova, and Pearson Correlation. Significance was considered at $\alpha \leq 0.05$.
\end{abstract}

Study findings: The prevalence of dyslipidemia was about $60 \%$. No significant relationships were found between dyslipidemia and study variables.

Conclusion: The results of the present study did not agree with most studies in existing literature which implies that further studies using large numbers of participants are required to generalize the results.

KEYWORDS: Diabetes, Dyslipidemia, gender, BMI, risk factors.

Corresponding Author: Khaled Waleed Alkurdi Indian Research Journal of Pharmacy and Science; 21(2019)1896-1900; E-mail: khaled.alkurdy@gmail.com Mobile: 0097335587403

Journal Home Page: https://www.irjps.in DOI: 10.21276/irjps.2019.6.2.10 


\section{INTRODUCTION}

Diabetes mellitus is considered a chronic disease with a chronic nature resulting from insulin deficiency or insulin resistance ending with hyperglycemia, which is associated with metabolic disorders of lipids, carbohydrates, and proteins ${ }^{1-3}$.

According to estimates of the International Diabetes Federation, approximately 425 million adults (20-79 years) suffer from diabetes in 2017, and it is expected that this number to reach 629 million by $2045^{4}$.

Dyslipidemia is considered as a significant risk factor for heart diseases. The diagnosis of dyslipidemia depends on increased levels of cholesterol, triglyceride, accompanied by diminished levels of high-density lipoprotein cholesterol. Anyhow, increased risk ofischemic stroke has been associated with dyslipidemia. Furthermore, it has been observed that there is an increased risk of mortality associated with cardiovascular diseases among patients with type 2 diabetes mellitus (T2DM) $)^{5-7}$.

Epidemiological studies pointed out to the occurrence of dyslipidemia in $53 \%$ of Americans ${ }^{8}$. Other studies conducted in middle-income Asian countries showed the prevalence of dyslipidemia in the range $78 \%$ in 2004 to $66.5 \%$ in 2009 among population of Thailand, 10 .

The relationship between dyslipidemia and body mass index (BMI) was shown to be significant ${ }^{11}$. Studies have provided evidence regarding the association of dyslipidemia with a high $\mathrm{BMI}^{12,13}$. BMI is considered as the most commonly used measurement predicting health risk related to weight status $^{14}$.

Gender was significantly correlated with dyslipidemia ${ }^{11}$. In a recent study by Milyani and AlAgha $^{15}$, no significant relationship was proved between dyslipidemia and gender.

\section{OBJECTIVES}

The main objective of this study was to investigate the impact of BMI and gender on the occurrence of dyslipidemia in diabetic patients treated outpatient clinics in Royal Medical services, Jordan.

\section{METHODS AND SUBJECTS}

\section{Study design and setting:}

This study was a retrospective and conducted in Royal Medical Services.

\section{Study sample:}

A total of 62 diabetic patients were included in this study.

Study variables:

The following variables were included in the present study: age, BMI, gender, and dyslipidemia.

\section{Study procedure:}

Files of diabetic patients were reviewed. Files included required variables were selected to be analyzed. A working excel sheet was created to make raw data. After completing of entering data into excel sheet, the analysis of data was accomplished using the software, SPSS 21. Data presentation took various styles as means and standard deviations, frequency and percentages. The relationships between variables were investigated through ChiSquare test, One Way Anova, and Pearson correlation. Significance was considered at $\alpha \leq 0.05$.

\section{RESULTS}

Table 1 shows the general characteristics of study participants. Mean age of participants was $61 \pm 12$ years. The mean of BMI was $32 \pm 12$. Slightly more than $50 \%$ of participants were males (about 53\%). About $60 \%$ of patients had dyslipidemia.

Table 1: General characteristics of study participants

\begin{tabular}{|c|c|}
\hline Variable & Description \\
\hline Age (M \pm SD) years & $\mathbf{6 1} \pm 12$ \\
\hline BMI & $32 \pm 21$ \\
\hline Gender (N, \%): & $\mathbf{3 3}(53.2 \%)$ \\
$-\quad$ Males & $\mathbf{2 9}(\mathbf{4 6 . 8 \% )}$ \\
\hline$\quad$ Females & $37(59.7 \%)$ \\
$-\quad$ Yes & $\mathbf{2 5}(\mathbf{4 0 . 3 \% )}$ \\
\hline Dyslipidemia $\mathbf{N}, \%):$ &
\end{tabular}


The impact of study variables including gender, BMI, and age on dyslipidemia was computed using One Way Anova. The results, as included in table 2, did not reveal any positive impact of studied variables on dyslipidemia $(\mathrm{p}>0.05)$.

Table 2: The impact of study variables on dyslipidemia

\begin{tabular}{|c|c|c|c|c|c|c|}
\hline & & $\begin{array}{c}\text { Sum of } \\
\text { Squares }\end{array}$ & df & $\begin{array}{c}\text { Mean } \\
\text { Square }\end{array}$ & $\mathbf{F}$ & Sig. \\
\hline \multirow[t]{3}{*}{ Age } & $\begin{array}{l}\text { Between } \\
\text { Groups }\end{array}$ & 18.896 & 1 & 18.896 & 0.130 & 0.720 \\
\hline & Within Groups & 8729.959 & 60 & 145.499 & & \\
\hline & Total & 8748.855 & 61 & & & \\
\hline \multirow[t]{3}{*}{$\begin{array}{l}\text { Gend } \\
\text { er }\end{array}$} & $\begin{array}{l}\text { Between } \\
\text { Groups }\end{array}$ & 0.114 & 1 & 0.114 & 0.448 & 0.506 \\
\hline & Within Groups & 15.321 & 60 & .255 & & \\
\hline & Total & 15.435 & 61 & & & \\
\hline \multirow[t]{3}{*}{ BMI } & $\begin{array}{l}\text { Between } \\
\text { Groups }\end{array}$ & 127.784 & 1 & 127.784 & 0.289 & 0.593 \\
\hline & Within Groups & 26575.231 & 60 & 442.921 & & \\
\hline & Total & 26703.015 & 61 & & & \\
\hline
\end{tabular}

The relationship between the gender and status of dyslipidemia was investigated through Chi-Square testing. Among males with diabetes, 48\% had dyslipidemia, and $52 \%$ of diabetic females had dyslipidemia. The results did not show a significant relationship between gender and dyslipidemia $(\mathrm{p}=0.638)($ table 3$)$.

Table 3: The relationship between gender and dyslipidemia

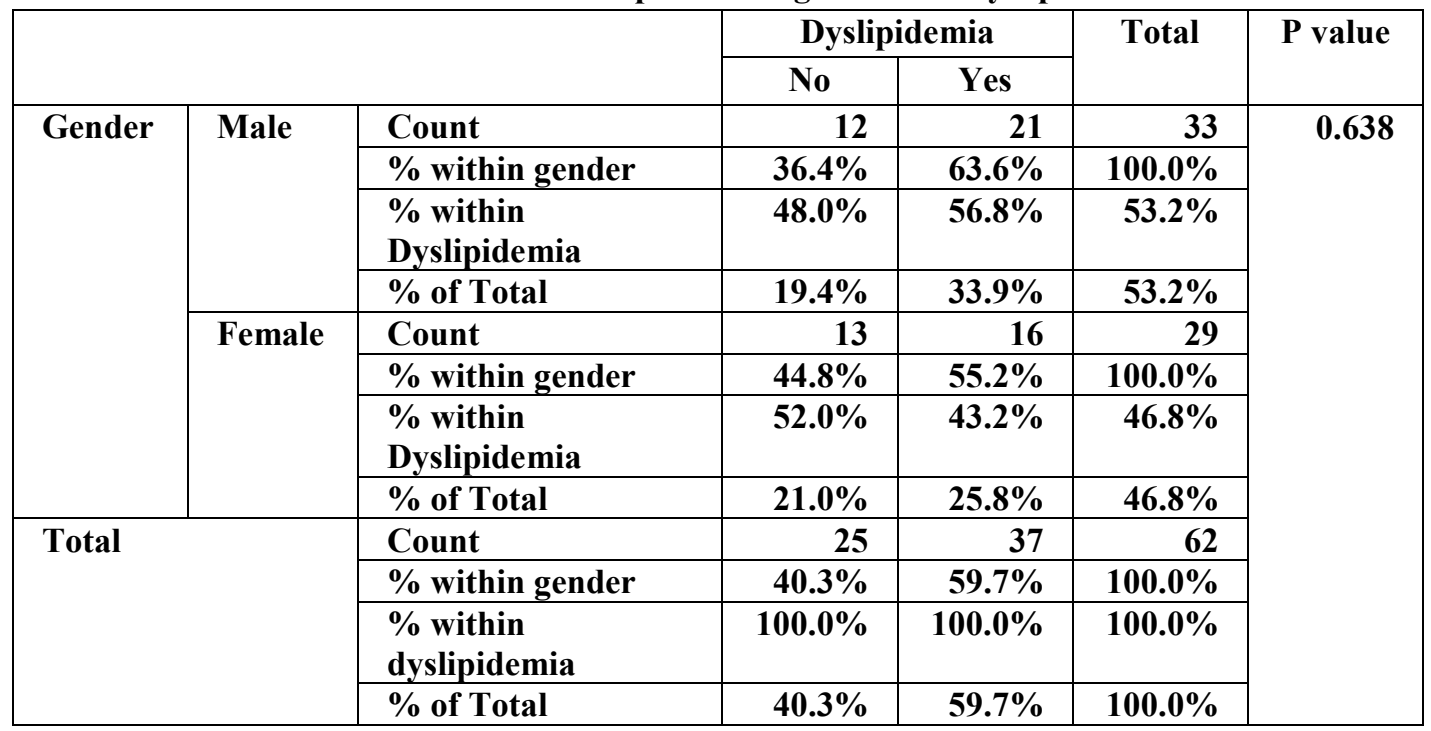

Correlation between study variables was studied were found among all variables ( $>0.05)$ (table 4). using Pearson correlation. No significant correlations 
Table 4: Correlation between study variables

\begin{tabular}{|c|c|c|c|c|c|}
\hline & & Age & Gender & BMI & $\begin{array}{c}\text { Dyslipidem } \\
\text { ia }\end{array}$ \\
\hline \multirow[t]{3}{*}{ Age } & $\begin{array}{l}\text { Pearson } \\
\text { Correlation }\end{array}$ & 1 & 0.004 & $-.101-$ & 0.046 \\
\hline & Sig. (2-tailed) & & 0.977 & 0.433 & 0.720 \\
\hline & $\mathbf{N}$ & 62 & 62 & 62 & 62 \\
\hline \multirow[t]{3}{*}{ Gender } & $\begin{array}{l}\text { Pearson } \\
\text { Correlation }\end{array}$ & 0.004 & 1 & $-.108-$ & 0-.086- \\
\hline & Sig. (2-tailed) & 0.977 & & 0.403 & 0.506 \\
\hline & $\mathbf{N}$ & 62 & 62 & 62 & 62 \\
\hline \multirow[t]{3}{*}{ BMI } & $\begin{array}{l}\text { Pearson } \\
\text { Correlation }\end{array}$ & $-.101-$ & -.108 & 1 & 0.069 \\
\hline & Sig. (2-tailed) & 0.433 & 0.403 & & 0.593 \\
\hline & $\mathbf{N}$ & 62 & 62 & 62 & 62 \\
\hline \multirow[t]{3}{*}{$\begin{array}{l}\text { Dyslipidem } \\
\text { ia }\end{array}$} & $\begin{array}{l}\text { Pearson } \\
\text { Correlation }\end{array}$ & 0.046 & $-.086-$ & .069 & 1 \\
\hline & Sig. (2-tailed) & 0.720 & 0.506 & 0.593 & \\
\hline & $\mathbf{N}$ & 62 & 62 & 62 & 62 \\
\hline
\end{tabular}

\section{DISCUSSION}

The present study aimed to investigate if the both gender and BMI have positive impacts on dyslipidemia in diabetic patients treated in out clinics at Royal medical services, Jordan.

The data of our results showed that the prevalence of dyslipidemia among diabetic patients was about $60 \%$. Actually, this is still lower than the prevalence of dyslipidemia in other Asian countries like Thai population whose dyslipidemia prevalence ranged from $66.5 \%$ to $78 \%{ }^{9}, 10$. Concerning studies from America, the prevalence of dyslipidemia in our study is higher than that reported in America, in which the reported dyslipidemia prevalence was $53 \%{ }^{8}$. We think that the awareness of physicians who are treating patients in addition to the availability of lipid lowering drugs may explain the difference in dyslipidemia prevalence. We also think that lack of physical activity helps in increased prevalence of dyslipidemia.

Using various statistical styles including Chi-Square, One Way Anova, and Pearson correlation did not provide any significant impact of age, gender, and BMI on dyslipidemia. Our results did not agree with other studies that significant impact of BMI on dyslipidemia $^{11-14}$. It is plausible to explain these findings by taking into consideration that the mean
BMI in our study was not elevated as compared with previous studies $^{11-14}$.

Gender was also significantly with dyslipidemia in other studies ${ }^{11-14}$, but a recent study did not show a significant relationship between gender and dyslipidemia $^{15}$, which supports our findings. We think that due to lack of large number of participants in this study, the relationship between gender and dyslipidemia may be not able to be generalized.

\section{CONCLUSION}

The present study showed that the prevalence of dyslipidemia in diabetic patients was about $60 \%$, and this was not affected by gender and BMI.

\section{REFERENCES:}

1- Jameson JL. Harrison's Endocrinology. 2nd ed. New York: Chicago; 2010.

2- Habib S. Frequency distribution of atherogenic dyslipidemia in Saudi type 2 diabetic patients. Pak J Physiol. 2006; 2(2):20-23.

3- Mooradian A. Dyslipidemia in type 2 diabetes mellitus. Nat ClinPractEndocrinolMetab. 2009;5(3):150159

4- International Diabetes Federation, IDF Diabetes Atlas, International Diabetes 
Federation, Brussels, Belgium, 8th edition, 2017.

5- Narindrarangkura P, Bosl W, Rangsin R, Hatthachote P. Prevalence of dyslipidemia associated with complications in diabetic patients: a nationwide study in Thailand. Lipids Health Dis. 2019;18(1):90. doi:10.1186/s12944-019-1034-3.

6- Qi L, Ding X, Tang W, Li Q, Mao D, Wang Y. Prevalence and risk factors associated with dyslipidemia in Chongqing, China. Int J Environ Res and Public Health. 2015;12:13455-65.

7- Houston M. Dyslipidemia. In: Integrative Medicine [Internet]. Elsevier; 2018 [cited 2019 Apr 4]. p. 264-75.e5. Available from: https://linkinghub.elsevier. com/retrieve/pii/B978032335868200027X.

8- Toth PP, Potter D, Ming EE. Prevalence of lipid abnormalities in the United States: the National Health and nutrition examination survey 2003-2006. J ClinLipidol. 2012;6:325-30

9- Kim H-S, Wu Y, Lin S-J, Deerochanawong C, Zambahari R, Zhao L, et al. Current status of cholesterol goal attainment after statin therapy among patients with hypercholesterolemia in Asian countries and region: the return on expenditure achieved for lipid therapy in Asia (REALITY-Asia) study. Curr Med Res Opin. 2008;24:195163.

10- Aekplakorn W, Taneepanichskul S, Kessomboon P, Chongsuvivatwong V, Putwatana P, Sritara P, et al. Prevalence of dyslipidemia and management in the Thai population, National Health Examination Survey IV, 2009. J Lipids. 2014;2014:249584.

11- Rao W, Su Y, Yang G, et al. Cross-Sectional Associations between Body Mass Index and Hyperlipidemia among Adults in Northeastern China. Int J Environ Res Public Health. 2016;13(5):516. Published 2016 May 20. doi:10.3390/ijerph13050516.

12- Brown C.D., Higgins M., Donato K.A., Rohde F.C., Garrison R., Obarzanek E., Ernst N.D., Horan M. Body mass index and the prevalence of hypertension and dyslipidemia. Obes. Res. 2000;8:605-619. doi: $10.1038 /$ oby.2000.79.

13- Brown C.D., Higgins M., Donato K.A., Rohde F.C., Garrison R., Obarzanek E., Ernst N.D., Horan M. Body mass index and the prevalence of hypertension and dyslipidemia. Obes. Res. 2000;8:605-619. doi: $10.1038 /$ oby.2000.79.

14- Song X., Jousilahti P., Stehouwer C., Söderberg S., Onat A., Laatikainen T., Yudkin J., Dankner R., Morris R., Tuomilehto J. Comparison of various surrogate obesity indicators as predictors of cardiovascular mortality in four European populations. Eur. J. Clin. Nutr. 2013;67:1298-1302. doi: 10.1038/ejen.2013.203.

15- Milyani AA, Al-Agha AE. The effect of body mass index and gender on lipid profile in children and adolescents in Saudi Arabia. Ann Afr Med. 2019;18(1):42-46. doi:10.4103/aam.aam_17_18 